\title{
Beneficial effects of retinoic acid on extracellular matrix degradation and attachment behaviour in follicular thyroid carcinoma cell lines
}

\author{
B Havekes, J P Schröder van der Elst, G van der Pluijm, \\ B M Goslings, J Morreau ${ }^{1}$, J A Romijn and J W A Smit
}

Department of Endocrinology and Metabolic Diseases, Leiden University Medical Centre, PO Box 9600, 2300 RC Leiden, The Netherlands

${ }^{1}$ Department of Pathology, Leiden University Medical Centre, PO Box 9600, 2300 RC Leiden, The Netherlands

(Requests for offprints should be addressed to J W A Smit, Department of Endocrinology and Metabolic Diseases, C4-R, Leiden University Medical Centre, PO Box 9600, 2300 RC Leiden, The Netherlands)

\begin{abstract}
The prognosis of patients with metastasised follicular thyroid carcinoma (FTC) is limited, necessitating the search for new treatment options. Beneficial effects of retinoids have been suggested in thyroid cancer and the present study was performed to investigate the effects of retinoic acid (RA) on important determinants of metastatic behaviour in FTC: the disengagement of tumour cells from the primary tumour and the degradation of extracellular matrix, focusing on the role of the plasmin activation system and the integrin and E-cadherin families of attachment molecules. Three FTC cell lines were studied: FTC-133, derived from the primary tumour; and FTC-236 and FTC-238, derived from metastases. FTC cell lines were cultured with $0 \cdot 1,1$ and $10 \mu \mathrm{M} 13$-cis-RA or with the solvent DMSO for 1 and 5 days. Extracellular matrix degradation by these cell lines was studied by assessing the 48 -h release of radioactivity from ${ }^{35} \mathrm{~S}$ methionine labelled extracellular matrix proteins synthesised by the MC3T3 cell line coated onto plastic. The involvement of constituents of the plasmin activation system was investigated by semi-quantitative RT-PCR and zymography. Attachment to extracellular matrix was studied by determining the number of adhering FTC cells to extracellular matrix coated onto plastic, $3 \mathrm{~h}$ after seeding. The involvement of attachment molecules was
\end{abstract}

studied by RT-PCR with primers for integrin subclasses and E-cadherin and immunofluorescence for E-cadherin. Five days culturing with $10 \mu \mathrm{M}$ RA reduced the degradation of extracellular matrix significantly in all cell lines: FTC -133 by $35 \%$, FTC-236 by $74 \%$ and FTC- 238 by $31 \%$. Zymography revealed diminished activity of urokinase type plasminogen activator (uPA) in FTC-236 and FTC-238, but not in FTC-133 cultured with RA. mRNA expression of the uPA receptor was diminished in FTC-236. In the attachment assay, $10 \mu \mathrm{M}$ RA for 5 days increased the number of adherent cells to extracellular matrix significantly by $91 \%$ in FTC-133, 64\% in FTC236 and $87 \%$ in FTC-238. No effects of RA on integrin or E-cadherin mRNA expression were observed. Immunofluorescence, however, revealed enhanced organisation of E-cadherin along the cell membrane by RA treatment. In conclusion, the present study demonstrates beneficial effects of RA on important determinants of metastatic behaviour in FTC cell lines, e.g. decreased degradation of extracellular matrix which may in part be explained by effects on the plasmin activation system and enhanced attachment to extracellular matrix. These findings may add to the explanations for beneficial effects of retinoids in thyroid cancer.

Journal of Endocrinology (2000) 167, 229-238

\section{Introduction}

Although the overall prognosis of differentiated thyroid cancer is favourable due to the combined treatment of surgery and radioactive iodine, about $50 \%$ of patients with distant metastases of follicular thyroid carcinoma (FTC) die within 10 years after the diagnosis (Hundahl et al. 1998). Important events in the metastatic process are the disengagement of tumour cells from the primary tumour and the degradation of extracellular matrix. The adherence of cells to neighbouring cells and extracellular matrix is mediated by attachment molecules (Akiyama \& Yamuda 1993). E-cadherin is a transmembrane protein that is usually located at adherens junctions in epithelial cells and mediates cell-cell adhesion. Integrins are transmembrane molecules consisting of $\alpha$ and $\beta$ subunits and mediate cellular attachment to extracellular matrix (Ruoslahti 1991, Serini et al. 1996). The $\beta_{1}$ subunit associates with a number of $\alpha$ subunits and constitutes the largest integrin subfamily. In many malignant tumours, loss of expression 
of E-cadherin and altered expression of integrins have been related to metastatic potential and poor prognosis (Juliano 1993, Serini et al. 1996). We have recently reported on integrin expression and attachment behaviour in FTC cell lines (Smit et al. 1998). In malignant tumours, an important role in the degradation of extracellular matrix is assigned to the plasmin activation system (Andreasen et al. 1997). Plasmin is a serine protease which degrades extracellular matrix proteins such as fibronectin, laminin and proteoglycans (Vassalli et al. 1991). Plasminogen can be converted to plasmin by the urokinase-type plasminogen activator (uPA) or the tissue-type plasminogen activator (tPA) system (Vassalli et al. 1991, Andreasen et al. 1997). uPA exerts its effects after binding to the uPA receptor (uPAR) which is present on the cell membrane (Mondino et al. 1999). The presence of uPAR has been demonstrated in many malignant tumours and uPAmediated plasminogen activation appears to be an important pathway in tumour invasion (Gaffney et al. 1994, Costantini et al. 1996, Xing \& Rabbani 1996). uPA can be inactivated by plasminogen activator inhibitors (PAI-1 and PAI-2) (Schneiderman \& Loskutoff 1991, Vassalli et al. 1991). Matrix metalloproteinases (MMPs), like MMP-2 and MMP-9, are a class of enzymes that are involved in matrix degradation by malignant tumours as well and can be activated by plasmin or independently of the plasmin activation system. MMP activity can be inhibited by tissue inhibitors of metalloproteinases (TIMP-1 and TIMP-2) (Parsons et al. 1997, Pijuan-Thompson et al. 1999). The expression of components of the plasmin activation system in thyroid cancer tissue samples has been demonstrated (Ito et al. 1996). We have demonstrated the involvement of the plasmin activation system in matrix degradation by FTC cell lines (Smit et al. 1999).

Although radioiodine is the mainstay of therapy for metastasised thyroid carcinoma (Schlumberger et al. 1996), alternative treatment modalities are being investigated (Smit et al. 2000). Retinoids are derivatives of vitamin A (retinol). Beneficial effects of retinoids have been reported in patients with promyelocytic leukaemia, melanoma and several types of carcinoma (Castaigne et al. 1990, Lotan 1991, McBurney et al. 1993). In vitro data suggest that retinoids inhibit tumour invasion. This has been observed in prostate and other carcinomas (Webber \& Waghray 1995, Vo et al. 1998, Benbow et al. 1999), meningioma (Pereda et al. 1999) and melanoma (Hendrix et al. 1990). One of the explanations may be decreased activity of uPA or tPA or enhanced expression of TIMPs (Hendrix et al. 1990, Waghray \& Webber 1995, Webber \& Waghray 1995). Furthermore, some recent studies report enhanced attachment of tumour cells to extracellular matrix by retinoids (Matarrese et al. 1998, Nakagawa et al. 1998, Pereda et al. 1999, Touhami et al. 1999). Alterations in the expression of adhesion molecules have been suggested as an explanation (Matarrese et al. 1998, Nakagawa et al. 1998, Touhami et al. 1999). In thyroid carcinoma cell lines and tissue samples, expression of retinoid receptors has been investigated, suggesting decreased expression of $\mathrm{RXR} \beta$ in anaplastic thyroid carcinoma as compared with differentiated thyroid carcinoma cell lines and decreased RXR $\beta$ expression in thyroid carcinoma tissues as compared with normal thyroid tissue (Schmutzler et al. 1998). Intervention with retinoids have been reported to ameliorate in vitro iodide uptake and $5^{\prime}$ deiodinase activity (Van Herle et al. 1990, Schreck et al. 1994). In an in vivo study, beneficial effects on iodine uptake behaviour were suggested (Schmutzler et al. 1998). In the present study, we investigated the effects of 13-cis-retinoic acid (RA) on the degradation of extracellular matrix and the role of the plasmin activation system in FTC cell lines, and the effects of RA on the attachment of these cell lines to extracellular matrix.

\section{Materials and Methods}

\section{Cell lines and culturing conditions}

Three FTC cell lines FTC-133, FTC-236 and FTC-238 were kindly donated by Dr Goretzki and Dr Simon, University of Düsseldorf, Germany. The cell lines were derived from a 42-year-old male patient with metastatic FTC. The FTC-133 cell line was derived from the primary tumour whereas the FTC-236 and FTC-238 cell lines were derived from distant metastases. The cell lines produce thyroglobulin and express thyroid peroxidase. Receptors for thyrotrophin and the retinoid receptors RXR and RAR have been demonstrated in these cell lines (Goretzki et al. 1990, Schmutzler et al. 1998). The cell lines were grown in Dulbecco's modified Eagle's medium (DMEM) and modified HAM-F12 medium 1:1 supplemented with $10 \%$ fetal bovine serum and penicillin/ streptomycin in a humidified incubator at $37^{\circ} \mathrm{C}$ and $5 \%$ $\mathrm{CO}_{2}$. During experiments, the cell lines were cultured in serum-free DMEM/HAM-F12 medium. Cells were cultured for different time periods as indicated in the experiments in medium containing $0 \cdot 1,1$ or $10 \mu \mathrm{M}$ 13-cis-RA (Life Technologies-Gibco BRL, Gaithersburg, MD, USA) or DMSO as solvent of RA (control). Cells were shielded from light by aluminium foil. To prevent possible interaction with the attachment of the cells to the culture dishes, RA and DMSO were added 1 day after seeding the cells. For all assays, tumour cells were cultured until approximately $90 \%$ confluency and dissociated into singlecell suspensions from the tissue culture flasks using $0 \cdot 05 \%$ EDTA in PBS for 3 min.

\section{Degradation of extracellular matrix}

Matrix degradation by the FTC cell lines was studied using an in vitro model of ${ }^{35} \mathrm{~S}$-methionine labelled extracellular matrix molecules (Ronday et al. 1997, Smit et al. 
1999). Extracellular matrix synthesised by MC3T3 includes collagen type I and IV, fibronectin, vitronectin laminin and glycosylated molecules (Sudo et al. 1983, Takeuchi et al. 1990). In short, ${ }^{35} \mathrm{~S}$-methionine labelled extracellular matrix proteins, obtained by culturing the mesenchymal cell line MC3T3 with ${ }^{35}$ S-labelled methionine, were coated overnight onto plastic 24-well plates at $4{ }^{\circ} \mathrm{C}$ and fixed with methanol $60 \%$. The FTC cell lines were cultured for 1 or 5 days in DMSO alone or with $0 \cdot 1,1$ or $10 \mu \mathrm{M}$ RA and seeded at a density of 100000 per well. Attachment of the cell lines to non-radioactive extracellular matrix coated onto plastic was verified by counting adhering cells in two non-overlapping microscopic fields after staining with Amido black, magnification $400 \times$, as previously described (Van der Pluijm et al. 1996). After $48 \mathrm{~h}$ at $37^{\circ} \mathrm{C}$, supernatant and coating (cells and extracellular matrix) from each well were collected into tubes and counted in a scintillation counter. Supernatant with DMSO from wells without FTC cells was collected to assess the spontaneous release of radioactivity. To rule out cell-independent effects of RA on degradation of extracellular matrix, RA was added to ${ }^{35} \mathrm{~S}$-methionine labelled matrix, without cells. To study the involvement of the plasmin activation system in matrix degradation, FTC cells, cultured without RA, were seeded in the presence of $200 \mathrm{U} / \mathrm{ml}$ aprotinin (Trasylol), a potent inhibitor of plasmin activation. The release of radioactivity for each well is expressed as a percentage of the total radioactivity per well according to the formula:

$$
\frac{A_{\text {sn }}}{A_{\text {sn }}+A_{\text {coating }}} \times 100 \%
$$

where $A_{\mathrm{sn}}=$ radioactivity (c.p.m.) of supernatants and $A_{\text {coating }}=$ activity of extracellular matrix coating.

Matrix degradation by the FTC cell lines is reflected by the release of radioactivity in the wells in which FTC cell lines were seeded minus the release of radioactivity in the wells without cells (spontaneous release). Each FTC cell line was studied in hexaplicate.

\section{Zymography}

Fibrinolytic enzyme activity was studied by zymography as described previously (Smit et al. 1999). In short, cell lines were cultured in serum-free medium with DMSO and those concentrations of RA that revealed significant reduction of matrix degradation. Protein concentrations of the supernatants were determined by the method of Lowry et al. (1951). Supernatants were electrophoresed on $10 \%$ polyacrylamide gels with sodium dodecylsulphate (SDS-PAGE), and plasminogen activator activities were visualised on fibrin/plasminogen containing agarose underlay gels according to the Granelli-Piperno and Reich method (Granelli-Piperno \& Reich 1978). Before electrophoresis, samples were incubated for $1 \mathrm{~h}$ at $37^{\circ} \mathrm{C}$ in
$2 \%$ SDS to induce activator activity in the plasminogen activator-PAI complexes. Homogenates of the breast carcinoma cell line ZR75-1 (American Type Culture Collection, Rockville, MD, USA) were used as standards. In one experiment RA was added to the supernatant of FTC cells cultured without RA, to assess whether RA affects activity of fibrinolytic enzymes directly.

\section{Semi-quantitative PCR and immunofluorescence for E-cadherin}

Total RNA from the three cell lines, cultured during $3 \mathrm{~h}$, $6 \mathrm{~h}, 24 \mathrm{~h}, 48 \mathrm{~h}$ and 5 days with the above-mentioned DMSO and RA concentrations was isolated according to Chomczynski (RNA-zol method) (Chomczynski \& Sacchi 1987). The RNA was reverse-transcribed and used as a template for PCR amplification. The internal standard pQA1 (Bouaboula et al. 1992, Van Bezooijen et al. 1998) was used to standardise cDNA for $\beta_{2}$ microglobulin expression by competitive PCR. PCR was performed using primers for the following integrins (extracellular matrix protein ligand are in parentheses ): $\beta_{1}$ (fibronectin, vitronectin, collagen), $\beta_{3}$ (vitronectin), $\beta_{4}$ (laminin), $\beta_{5}$ (vitronectin), $\beta_{6}$ (fibronectin), $\alpha_{1}$ and $\alpha_{2}$ (collagen), $\alpha_{3}$ (laminin), $\alpha_{4}$ and $\alpha_{5}$ (fibronectin), $\alpha_{6}$ (laminin), $\alpha_{8}$ (fibronectin, vitronectin, tenascin), $\alpha_{9}$ (tenascin) and $\alpha_{\mathrm{v}}$ (vitronectin); E-cadherin; uPA, uPAR, tPA, PAI-1, PAI-2; MMP-2 and MMP-9; TIMP-1 and TIMP-2. Primer sequences are available from the authors upon request. PCR conditions were $95^{\circ} \mathrm{C}$ for $5 \mathrm{~min}, 29-38$ cycles of $95{ }^{\circ} \mathrm{C}$ for $20 \mathrm{~s}, 56{ }^{\circ} \mathrm{C}$ for $60 \mathrm{~s}$ and $72{ }^{\circ} \mathrm{C}$ for $30 \mathrm{~s}$, followed by extension at $72{ }^{\circ} \mathrm{C}$ for $3 \mathrm{~min}$. The PCR products were resolved on $1.5 \%$ agarose gels and visualised by ethidium bromide staining. Oligonucleotides for PCR amplification were synthesised by Isogen (Maarssen, The Netherlands) or Eurogentec (Seraing, Belgium). In addition, E-cadherin protein expression was investigated by immunofluorescence using a mouse anti-human monoclonal antibody against E-cadherin (Transduction Laboratories, Toronto, Canada). The canine kidney cell line MDCK was used as a positive control.

\section{Cell attachment assay}

The attachment of FTC cells to extracellular matrix was performed as described previously (Van der Pluijm et al. 1996, Smit et al. 1998, 1999). In short, extracellular matrix derived from the MC3T3 cell line as described in the 'Degradation of extracellular matrix' section was coated onto 96-well plates overnight at $4{ }^{\circ} \mathrm{C}$. Methanol $(100 \mu \mathrm{l}$ $60 \%$ ) was added to each well for $2 \mathrm{~h}$ at $4{ }^{\circ} \mathrm{C}$ and the wells were washed for $30 \mathrm{~min}$ at $4{ }^{\circ} \mathrm{C}$ with washing buffer $(50 \mathrm{mM}$ Tris- $\mathrm{HCl}$ (pH 7.8), $110 \mathrm{mM} \mathrm{NaCl}, 5 \mathrm{mM}$ $\mathrm{CaCl}_{2}, \quad 0.1 \mathrm{mM}$ phenylmethylsulphonyl fluoride, $1 \%$ 

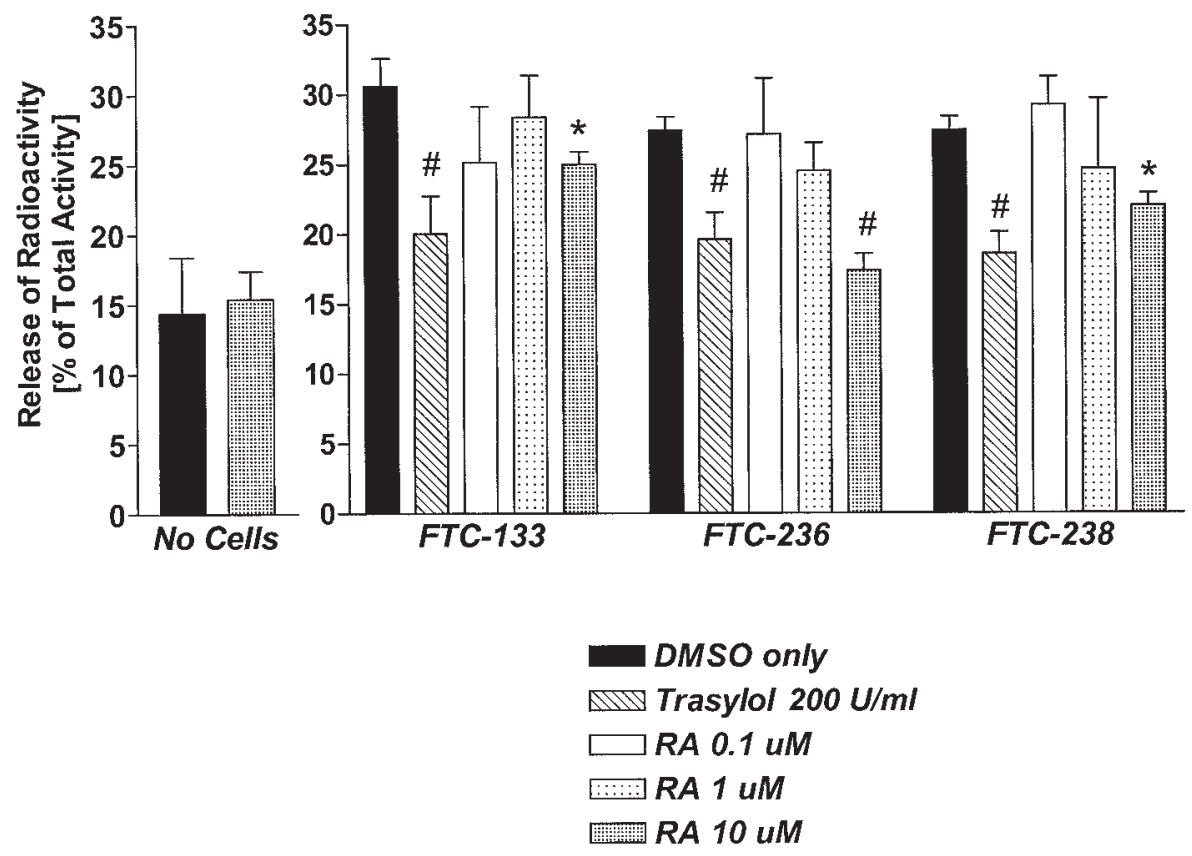

Figure 1 Effects of 13 -cis-RA and aprotinin (Trasylol; $200 \mathrm{U} / \mathrm{ml}$ ) on degradation of ${ }^{35} \mathrm{~S}$-methionine labelled extracellular matrix synthesised by the MC3T3 cell line coated onto plastic. The three FTC cell lines were cultured for 5 days with RA $0 \cdot 1,1$ and $10 \mu \mathrm{M}$ or DMSO and seeded at a density of 100000 per well. After $48 \mathrm{~h}$, radioactivity in the supernatant and coating were measured. Release of radioactivity is expressed as the radioactivity of the supernatant as a percentage of total radioactivity per well. Matrix degradation is reflected by the release of radioactivity from wells containing FTC cells minus the release of radioactivity from wells without cells. For formula, see text. Results are expressed as means \pm S.D. ${ }^{*} P<0 \cdot 05 ;{ }^{\#} P<0 \cdot 01$.

BSA, and $0 \cdot 1 \mu \mathrm{M}$ sodium azide) to block unbound sites on the plastic. The FTC cell lines were cultured for 1 and 5 days with RA and DMSO concentrations as mentioned. The FTC cells were dissociated with $0 \cdot 05 \%$ EDTA. Cells were seeded in serum-free medium (DMEM/HAM-F12) supplemented with glutamine and $0 \cdot 5 \%$ insulin, transferrin and selenium solution (ITS, Life Technologies-Gibco BRL) at a density of approximately 8000 per well. The 96-well plates were incubated at $37^{\circ} \mathrm{C}$ for $3 \mathrm{~h}$. After washing, the adhering cells were fixed with methanol and stained with Amido Black. Two non-overlapping microscopic fields within each well were counted (magnification $300 \times$ ). To study whether RA or DMSO affect attachment directly, in a separate experiment, RA and DMSO were added after seeding FTC cells onto the 96-well plates that were pre-cultured without RA.

\section{Statistics}

All results are presented as means \pm S.D. Comparison with controls was performed using a two-tailed unpaired Student's $t$-test or analysis of variance. A $P$ value $<0 \cdot 05$ was considered significant.

\section{Results}

Effects of $R A$ on degradation of extracellular matrix

All cell lines attached rapidly $(<1 \mathrm{~h})$ to non-radioactive serum free conditioned medium coated onto plastic. No differences in attachment were observed between the three cell lines. No proliferation of the cell lines was observed in the $48 \mathrm{~h}$ after seeding (data not shown). Data on matrix degradation are given in Fig. 1. Release of radioactivity during $48 \mathrm{~h}$ in wells with DMSO alone, without cells, was $14 \pm 4 \%$ of total radioactivity. This did not differ from wells with $10 \mu \mathrm{M}$ RA without cells $(15 \pm 2 \%)$. Differences between the three cell lines in matrix degradation were observed: matrix degradation (release of radioactivity observed in wells containing FTC cells minus spontaneous release (14\%)) in FTC-133 with DMSO alone was more prominent than in the other cell lines cultured with DMSO alone - FTC-133: $16 \pm 2 \%$ (calculated from $30 \pm 2 \%$ release of radioactivity in FTC133 containing wells minus $14 \%$ spontaneous release); FTC-236: $13 \pm 1 \% \quad(27 \pm 1 \%-14 \%)$; and FTC-238: $13 \pm 1 \%(27 \pm 1 \%-14 \%), P<0 \cdot 05$ vs FTC-133. Addition of aprotinin inhibited matrix degradation to a considerable 


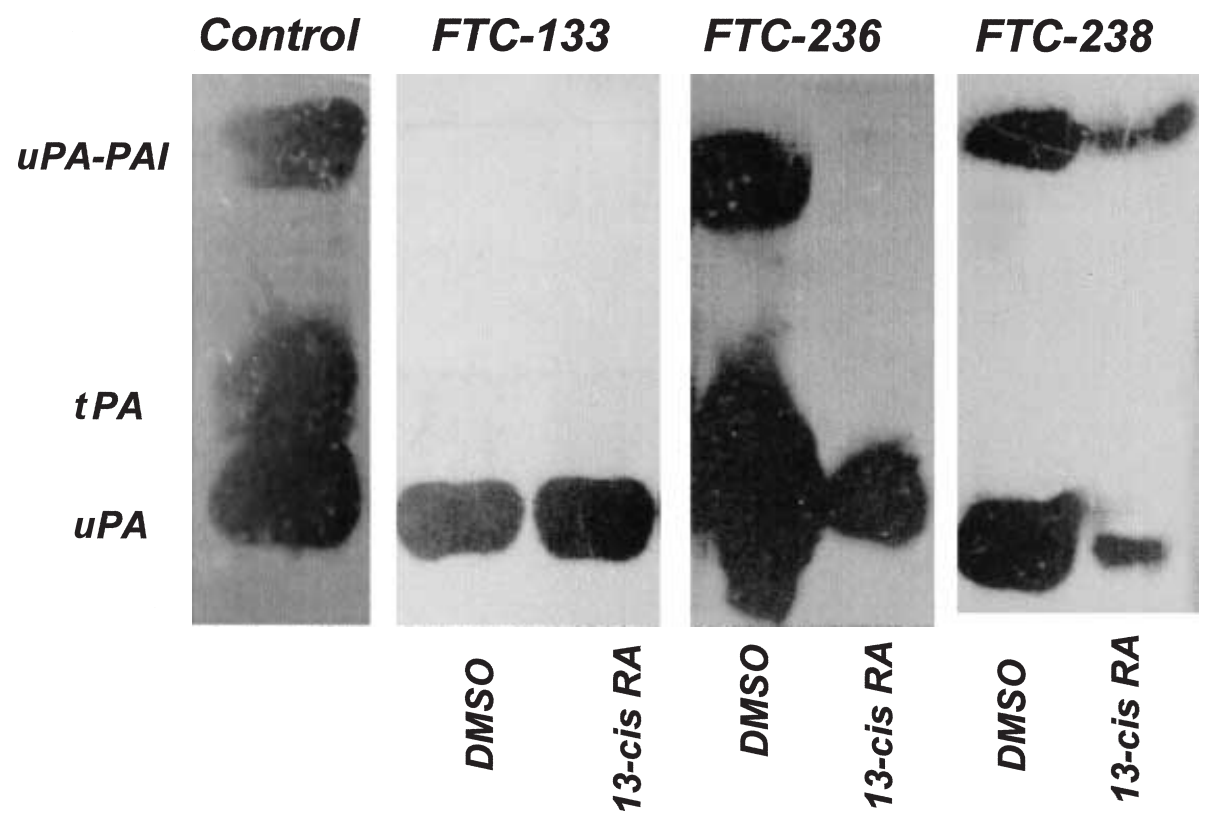

Figure 2 Zymographic analysis of plasminogen activator activity in FTC cell lines cultured for 5 days with $10 \mu \mathrm{M}$ 13-cis-RA or DMSO. In FTC-133, no expression of UPA-PAI complexes (110 kDa) is observed in contrast with FTC-236 and FTC-238. The uPA observed at zymography is the $54 \mathrm{kDa}$ variant. RA treatment results in decreased UPA and UPA-PAI activity in FTC-236 and FTC-238, whereas in FTC-133 uPA activity is similar. Control is the ZR75-1 cell line.

extent in all cell lines. In the FTC cell lines cultured for 1 day with RA, no effects on matrix degradation were observed. In the FTC cell lines cultured for 5 days with RA, significant reductions in matrix degradation were observed with $10 \mu \mathrm{M}$ RA: in FTC-133 extracellular matrix degradation was reduced to $10 \pm 1 \%(24 \%-14 \%)$ and in FTC-238 to $8 \pm 1 \%(22 \%-14 \%)(P<0.05$ vs FTC cells cultured with DMSO only). In FTC-236, matrix degradation by cells cultured for 5 days with $10 \mu \mathrm{M}$ RA was $3 \pm 2 \%(17 \%-14 \%, P<0 \cdot 01$ vs FTC-236 cultured with DMSO only).

\section{Zymography}

Zymography was performed with cells cultured for 5 days with $10 \mu \mathrm{M}$ RA as this condition revealed significant reductions in extracellular matrix degradation. The results of zymography are given in Fig. 2. All three cell lines exhibited uPA activity $(54 \mathrm{kDa})$, whereas no tPA activity could be found. Clear uPA-PAI complexes $(110 \mathrm{kDa})$ were observed in FTC-236 and FTC-238 in contrast with FTC-133, as observed before (Smit et al. 1999). Supernatants of cells cultured for 5 days together with $10 \mu \mathrm{M}$ 13-cis-RA revealed a clear decrease of uPA activity in FTC-236 and FTC-238, with the most prominent reduction in FTC-236. In the FTC-133 cell line, uPA activity appeared not to be influenced by RA. Expression of
uPA-PAI complexes was decreased in FTC-236 and FTC-238.

\section{Semi-quantitative RT-PCR and immunofluorescence for E-cadherin}

RT-PCR revealed no mRNA expression at any point of time of tPA, PAI-2, integrin subunits $\beta_{4}, \beta_{6}$ and $\alpha_{3}, \alpha_{6}, \alpha_{7}$ and $\alpha_{8}$; MMP-9 and TIMP-1. mRNAs of uPA (Fig. $3 a$ ), MMP-2, TIMP-2 and integrin subunits $\beta_{1}, \beta_{3}, \beta_{5}$ and $\alpha_{1}$, $\alpha_{2}, \alpha_{5}$ and $\alpha_{v}$ were expressed in all three cell lines to the same extent at all points of time and no influence of RA was observed. As observed previously (Smit et al. 1999) PAI-1 mRNA expression was lower in FTC-133 than in FTC-236 and FTC-238 without influence of RA (Fig. 3a). Integrin $\alpha_{9}$ expression was lower in FTC-236 than in FTC-133 and FTC-238, without effect of RA, whereas $\alpha_{4}$ mRNA was more prominent in FTC-236 (Fig. 3b). E-cadherin and uPAR mRNA expression were only detectable after $48 \mathrm{~h}$ culture (Fig. $3 c$ ). E-cadherin mRNA expression was not influenced by RA. The only effect of RA was observed on uPAR mRNA expression: uPAR mRNA expression was clearly diminished in FTC-236 cultured with RA, whereas it was unaffected in FTC-133 and FTC-238 (Fig. 3c).

Immunofluorescence of E-cadherin did not reveal increased expression of E-cadherin. However, a tendency 
(a) UPA
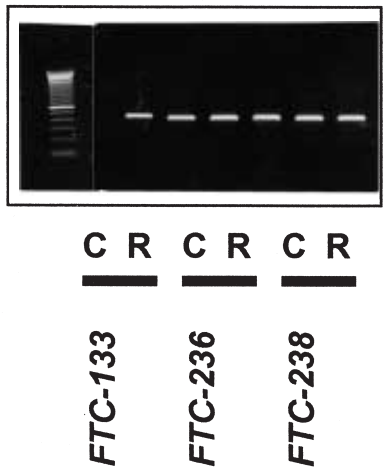

PAl-1
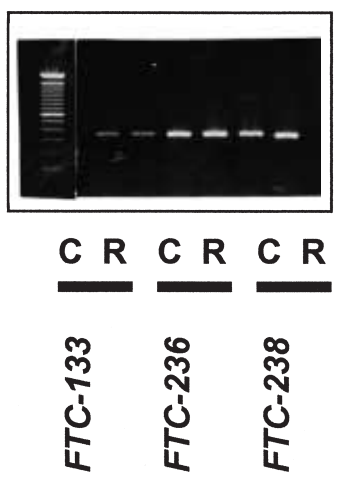

(b)

FTC-133

FTC-236

FTC-238
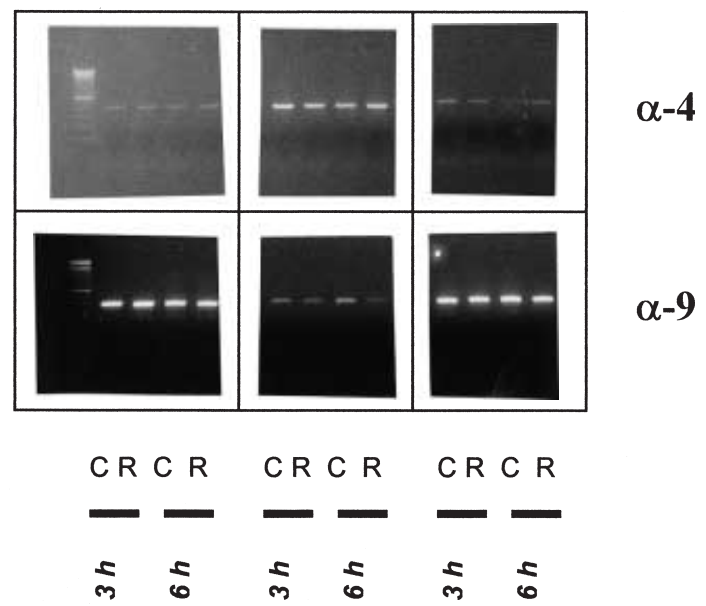

(c)

\section{UPAR}

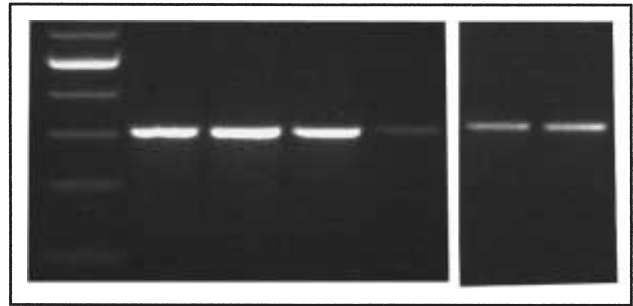

$\begin{array}{llllll}\text { C } & \mathbf{R} & \mathbf{C} & \mathbf{R} & \mathbf{C} & \mathbf{R}\end{array}$
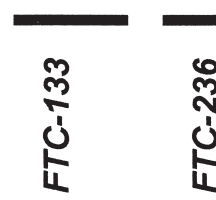

Figure 3 RT-PCR of integrin subunits, constituents of the plasmin activation system and E-cadherin. (a) uPA and PAI-1 mRNA expression of FTC cells cultured for $6 \mathrm{~h}$ in $10 \mu \mathrm{M} 13$-cis-RA or DMSO, 29 cycles, $56{ }^{\circ} \mathrm{C}$. (b) Integrin $\alpha_{4}$ and $\alpha_{9}$ mRNA expression of FTC cells cultured for 3 and $6 \mathrm{~h}$ in $10 \mu \mathrm{M}$ RA, 33 cycles. (c) uPAR and E-cadherin mRNA expression of FTC cells cultured for $48 \mathrm{~h}$ in $10 \mu \mathrm{M}$ RA, 38 cycles C, DMSO; R, RA.

of E-cadherin to organise along the cell membrane could be observed in $23 \%$ of the cells cultured with $10 \mathrm{mM}$ RA, assessed by counting three fields of vision for the FTC cell lines (magnification $400 \times$ ) (Fig. 4).

\section{Cell attachment assay}

The effects of RA on attachment of the FTC cell lines to extracellular matrix are given in Fig. 5. RA added to the FTC cells after seeding did not influence the attachment. After 1 day, only FTC-133 cultured with $10 \mu \mathrm{M}$ RA showed increased attachment $(+89 \%, P<0 \cdot 05)$. After 5 days, attachment in all three cell lines cultured with $10 \mu \mathrm{M}$ RA was enhanced strongly, as compared with
DMSO controls - FTC-133:+91\% $(P<0 \cdot 01)$; FTC236: $+64 \%(P<0 \cdot 01)$; and FTC-238: $+87 \%(P<0 \cdot 05)$.

\section{Discussion}

The present study was performed to assess the putative beneficial effects of 13-cis-RA on degradation of extracellular matrix and the attachment to extracellular matrix in FTC cell lines. A clear reduction in extracellular matrix degradation by RA was observed in all three cell lines. The most prominent effect was observed in the FTC-236 cell line. Zymography revealed clear reductions in uPA activity in FTC-236 and FTC-238 cultured for 5 days 


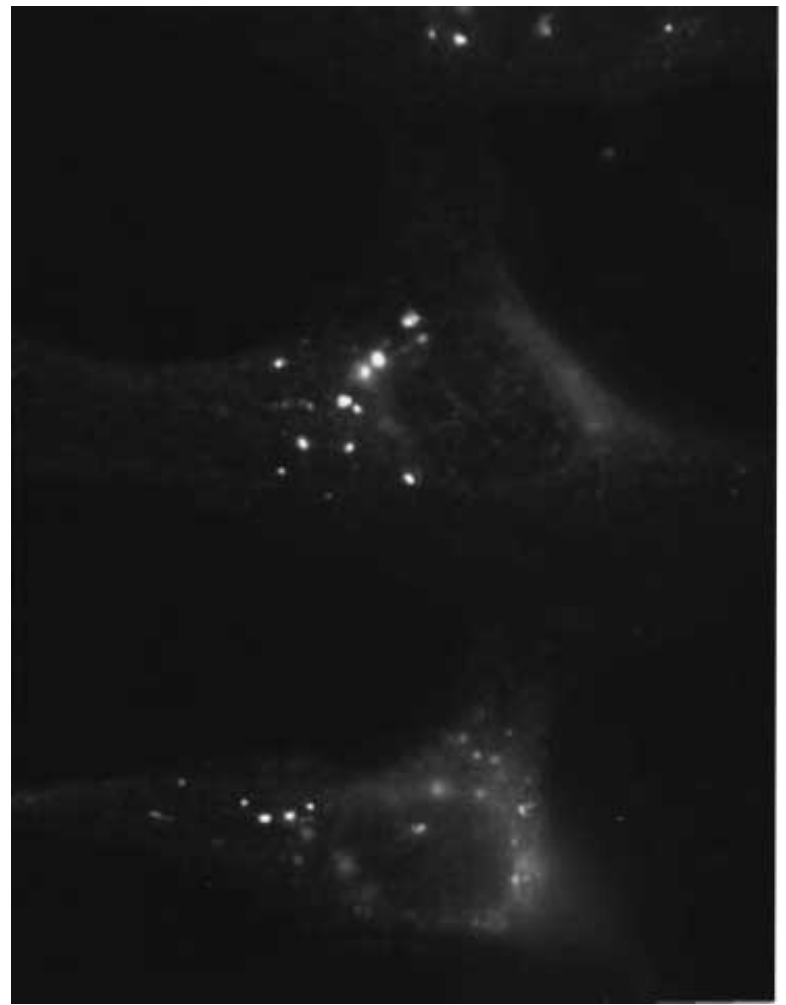

a

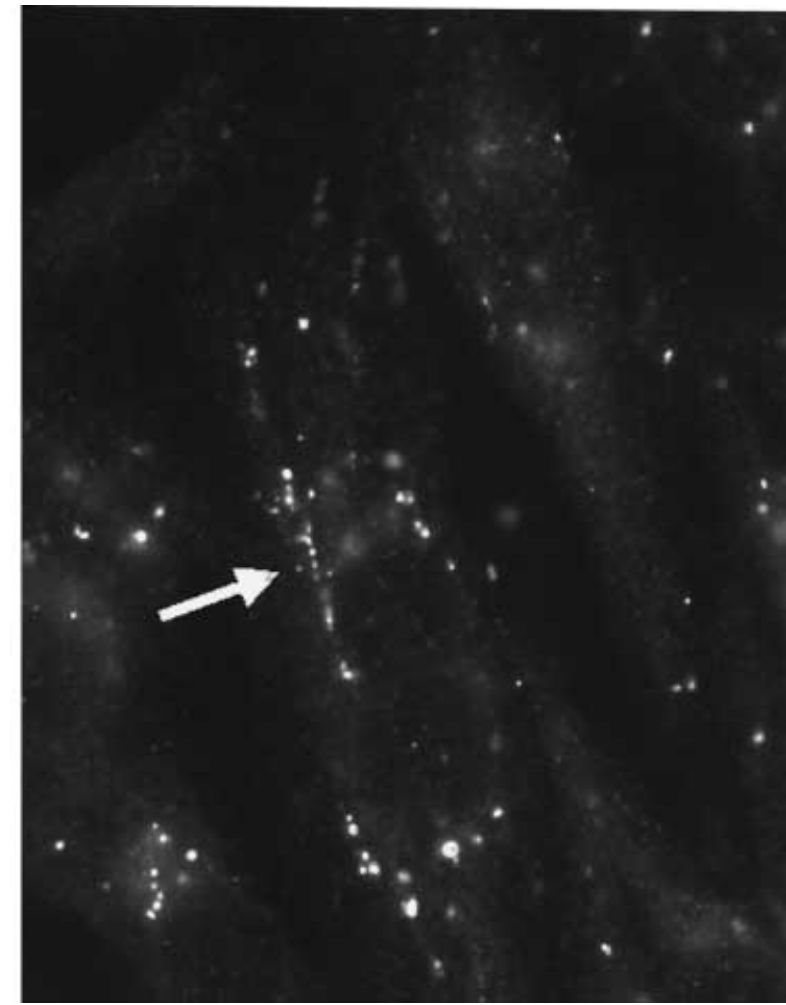

b

Figure 4 Immunofluorescence of FTC cell lines cultured with $10 \mu \mathrm{M}$ 13-cis-RA or DMSO for 5 days. Immunofluorescence was performed with a mouse anti-human monoclonal antibody and a goat anti-human fluorescence labelled second antibody. The MDCK cell lines was used as a positive control. Magnification is $300 \times$. (a) FTC-133 cultured with DMSO. (b) FTC-133 cultured with RA: cell-cell contact is more prominent. The arrow indicates organisation of E-cadherin along the cell membrane as observed in $23 \%$ of cells.

with $10 \mu \mathrm{M}$ RA, with the most impressive reduction in FTC-236, whereas no effects were observed in FTC-133. Decreased activity of uPA-PAI complexes in FTC-236 and FTC-238 were observed as well, so that the decreased uPA activity cannot be explained by increased binding to PAI. No effects of RA on uPA mRNA were observed.
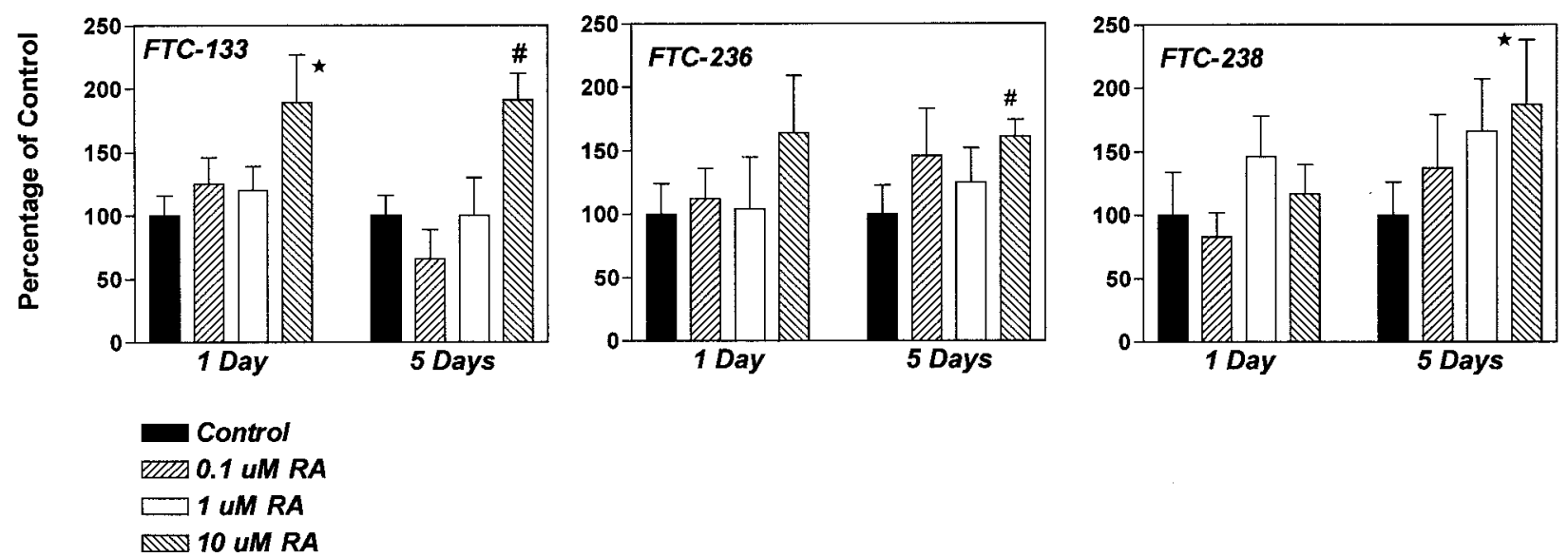

Figure 5 Attachment of FTC cell lines, cultured for 1 and 5 days in 0·1, 1 and $10 \mu \mathrm{M}$ 13-cis-RA or DMSO (control) to extracellular matrix coated onto plastic. Cells were counted $3 \mathrm{~h}$ after seeding. Attachment is reflected as the number of cells/area at a magnification of $400 \times$. Results are expressed as means \pm S.D. ${ }^{*} P<0 \cdot 05 ;{ }^{\#} P<0 \cdot 01$. 
However, uPAR mRNA expression in FTC-236 appeared to be decreased by RA. Thus, decreased matrix degradation by RA in FTC-236 and FTC-238 may be explained by decreased uPA activity, which appears to be post-translational. In FTC-236, the decreased uPAR mRNA expression may contribute to the effect, as uPAR is a prerequisite for uPA activity (Mondino et al. 1999). The finding of decreased uPAR mRNA expression by RA has not been reported before.

Most studies performed so far investigated invasion of tumour cells through artificial membranes and not degradation of extracellular matrix per se. However, the decreased activity of plasmin activators is in line with studies on invasive behaviour in prostate carcinoma cell lines and melanoma (Hendrix et al. 1990, Waghray \& Webber 1995, Webber \& Waghray 1995). Although RA reduced extracellular matrix degradation by FTC-133, no clear effects of RA on uPA activity at zymography was observed. Apparently, other enzymes involved in degradation of extracellular matrix may play a role. RA has been reported to decrease mRNA expression of MMPs (Hendrix et al. 1990, Schoenermark et al. 1999). However, we did not find effects of RA on MMP mRNA expression. No effects of RA on expression of TIMPs were observed either. The more prominent matrix degradation in FTC-133 as compared with the other cell lines is in line with earlier experiments and could be correlated to diminished PAI mRNA expression in FTC-133.

Attachment of the cell lines to extracellular matrix was enhanced considerably by RA. In recent reports, similar effects of RA on the attachment of other tumour cell lines to extracellular matrix have been observed (Matarrese et al. 1998, Nakagawa et al. 1998, Pereda et al. 1999, PijuanThompson et al. 1999). Several explanations can be proposed. First, RA treatment may affect the expression of attachment molecules, such as integrins or E-cadherin. In the literature no consistent effects of RA on integrins are described, some studies reporting increased, unaltered or decreased expression of integrin subclasses $\alpha_{v}, \alpha_{3}, \alpha_{4}, \alpha_{5}$, $\beta_{1}, \beta_{3}, \beta_{4}$ and $\beta_{5}$ (Dedhar et al. 1991, Morini et al. 1999, Pijuan-Thompson et al. 1999, Touhami et al. 1999). We found no effects of RA on integrin mRNA expression. The differences in $\alpha_{4}$ and $\alpha_{9}$ integrin mRNA expression as observed between the cell lines were not influenced by RA. In two studies in human malignant tumours, RA was reported to increase E-cadherin mRNA and protein expression (Hoang-Vu et al. 1998, Matarrese et al. 1998). In the present study, we found an indication that RA treatment had an effect on the organisation of E-cadherin. Interestingly, this was also observed in a study of RA in colon carcinoma (Nakagawa et al. 1998). An alternative explanation for the enhanced attachment of the thyroid carcinoma cell lines to extracellular matrix by RA treatment in this study may be the decreased proteolytic activity of the cell lines. It was found previously that the expression of $\operatorname{RAR} \alpha, \beta$ and $\gamma$ and $\operatorname{RXR} \alpha$ and $\beta$ were expressed by all FTC cell lines but that $\operatorname{RAR} \alpha$ and $\operatorname{RAR} \beta$ expression were decreased in FTC-238 as compared with the other FTC cell lines (Schmutzler et al. 1998). The differences in RA response by the three cell lines can therefore not be related to differences in retinoid receptor expression.

As the three cell lines are derived from the same patient, the differences between the cell lines are remarkable. Clonal selection within the primary tumour resulting in subclones with different characteristics with respect to the plasmin activation system may be responsible for these differences. Another possibility is that the microenvironment from which the metastatic cells were derived has influenced their phenotype.

In conclusion, the present study demonstrates the beneficial effects of RA on important characteristics of metastatic behaviour in three related FTC cell lines. The degradation of extracellular matrix was decreased whereas the attachment to extracellular matrix was enhanced. Evidence is found for effects of RA on the plasmin activation system, e.g. diminished uPA activity and uPAR mRNA expression. However, other mechanisms, independent of the plasmin activation system, may be involved as well. The beneficial effects on attachment to extracellular matrix may be explained by decreased proteolytic activity or enhanced functional E-cadherin expression. As these studies were performed in cell lines only, the implications of our findings for clinical practice are not clear and may not be translated unconditionally to the clinic. It would be worthwhile to investigate the relation between the expression of retinoid receptor subclasses and clinical behaviour in tissue samples derived from thyroid carcinoma. However, the results of the present study may add to the understanding of the mechanisms of the beneficial effects of retinoids as observed in thyroid carcinoma and offer perspectives for further investigations into the application of retinoids in thyroid carcinoma.

\section{References}

Akiyama SK \& Yamada KM 1993 Introduction: adhesion molecules in cancer. Part I. Seminars in Cancer Biology 4 215-218.

Andreasen PA, Kjoller L, Christensen L \& Duffy MJ 1997 The urokinase-type plasminogen activator system in cancer metastasis: a review. International Journal of Cancer 72 1-22.

Benbow U, Schoenermark MP, Orndorff KA, Givan AL \& Brinckerhoff CE 1999 Human breast cancer cells activate procollagenase-1 and invade type I collagen: invasion is inhibited by all-trans retinoic acid. Clinical and Experimental Metastasis 17 231-238.

Bouaboula M, Legoux P, Pessegue B, Delpech B, Dumont X, Piechaczyk M, Casellas P \& Shire D 1992 Standardization of mRNA titration using a polymerase chain reaction method involving co-amplification with a multispecific internal control. Journal of Biological Chemistry 267 21830-21838.

Castaigne S, Chomienne C, Daniel MT, Ballerini P, Berger R, Fenaux P \& Degos L 1990 All-trans retinoic acid as a 
differentiation therapy for acute promyelocytic leukemia. I. Clinical results. Blood 76 1704-1709.

Chomczynski P \& Sacchi N 1987 Single-step method of RNA isolation by acid guanidinium thiocyanate-phenol-chloroform extraction. Analytical Biochemistry 162 156-159.

Costantini V, Sidoni A, Deveglia R, Cazzato OA, Bellezza G, Ferri I, Bucciarelli E \& Nenci GG 1996 Combined overexpression of urokinase, urokinase receptor, and plasminogen activator inhibitor-1 is associated with breast cancer progression: an immunohistochemical comparison of normal, benign, and malignant breast tissues. Cancer $\mathbf{7 7}$ 1079-1088.

Dedhar S, Robertson K \& Gray V 1991 Induction of expression of the alpha $\mathrm{v}$ beta 1 and alpha $\mathrm{v}$ beta 3 integrin heterodimers during retinoic acid-induced neuronal differentiation of murine embryonal carcinoma cells. Journal of Biological Chemistry 266 21846-21852.

Gaffney PJ, Cooke DA \& Burnand KG 1994 Urokinase and its receptor: marker of malignancy? Advances in Experimental Medicine and Biology 360 187-191.

Goretzki PE, Frilling A, Simon D \& Roeher HD 1990 Growth regulation of normal thyroids and thyroid tumors in man. Recent Results in Cancer Research 118 48-63.

Granelli-Piperno A \& Reich E 1978 A study of proteases and protease-inhibitor complexes in biological fluids. Journal of Experimental Medicine 148 223-234.

Hendrix MJ, Wood WR, Seftor EA, Lotan D, Nakajima M, Misiorowski RL, Seftor RE, Stetler-Stevenson WG, Bevacqua SJ \& Liotta LA 1990 Retinoic acid inhibition of human melanoma cell invasion through a reconstituted basement membrane and its relation to decreases in the expression of proteolytic enzymes and motility factor receptor. Cancer Research 50 4121-4130.

Hoang-Vu C, Schmutzler C, Schwartz I, Bull K, Aust G, Kohrle J \& Dralle H 1998 Effects of retinoic acid on protein expression of CD97 and E-cadherin in the human thyroid cell line FTC-133. Journal of Endocrinological Investigation 21 (Suppl) 14-14.

Hundahl SA, Fleming ID, Fremgen AM \& Menck HR 1998 A National Cancer Data Base report on 53,856 cases of thyroid carcinoma treated in the U.S., 1985-1995. Cancer 83 2638-2648.

Ito Y, Takeda T, Kobayashi T, Wakasugi E, Tamaki Y, Umeshita K, Monden T, Shimano T \& Monden M 1996 Plasminogen activation system in active even in thyroid tumors; an immunohistochemical study. Anticancer Research 16 81-89.

Juliano RL 1993 The role of beta 1 integrins in tumors. Seminars in Cancer Biology 4 277-283.

Lotan R 1991 Retinoids as modulators of tumor cells invasion and metastasis. Seminars in Cancer Biology 2 197-208.

Lowry OH, Rosebrough NJ, Farr AL \& Randall R 1951 Protein measurement with the Folin phenol reagent. Journal of Biological Chemistry 193 265-275.

Matarrese P, Giandomenico V, Fiorucci G, Rivabene R, Straface E, Romeo G, Affabris E \& Malorni W 1998 Antiproliferative activity of interferon alpha and retinoic acid in $\mathrm{SiHa}$ carcinoma cells: the role of cell adhesion. International Journal of Cancer 76 531-540.

McBurney MW, Costa S \& Pratt MA 1993 Retinoids and cancer: a basis for differentiation therapy. Cancer Investigation 11 590-598.

Mondino A, Resnati M \& Blasi F 1999 Structure and function of the urokinase receptor. Thrombosis and Haemostasis 82 (Suppl 1) 19-22.

Morini M, Piccini D, De Santanna A, Levi G, Barbieri O \& Astigiano S 1999 Localization and expression of integrin subunits in the embryoid bodies of F9 teratocarcinoma cells. Experimental Cell Research 247 114-122.

Nakagawa K, Sogo S, Hiok K, Tokunaga R \& Taketani S 1998 Acquisition of cell adhesion and induction of focal adhesion kinase of human colon cancer Colo 201 cells by retinoic acid-induced differentiation. Differentiation 62 249-257.

Parsons SL, Watson SA, Brown PD, Collins HM \& Steele RJ 1997 Matrix metalloproteinases. British Journal of Surgery 84 160-166.
Pereda MP, Hopfner U, Pagotto U, Renner U, Uhl E, Arzt E, Missale C \& Stalla GK 1999 Retinoic acid stimulates meningioma cell adhesion to the extracellular matrix and inhibits invasion. British Journal of Cancer 81 381-386.

Pijuan-Thompson V, Grammer JR, Stewart J, Silverstein RL, Pearce SF, Tuszynski GP, Murphy-Ullrich JE \& Gladson CL 1999 Retinoic acid alters the mechanism of attachment of malignant astrocytoma and neuroblastoma cells to thrombospondin-1. Experimental Cell Research 249 86-101.

Ronday HK, Smits HH, Quax PH, Van der Pluijm G, Lowik CW, Breedveld FC \& Verheijen JH 1997 Bone matrix degradation by the plasminogen activation system. Possible mechanism of bone destruction in arthritis. British Journal of Rheumatology 36 9-15.

Ruoslahti E 1991 Integrins. Journal of Clinical Investigation 87 1-5.

Schlumberger M, Challeton C, De Vathaire F, Travagli JP, Gardet P, Lumbroso JD, Francese C, Fontaine F, Ricard M \& Parmentier C 1996 Radioactive iodine treatment and external radiotherapy for lung and bone metastases from thyroid carcinoma. Journal of Nuclear Medicine 37 598-605.

Schmutzler C, Brtko J, Winzer R, Jakobs TC, Meissner-Weigl J, Simon D, Goretzki PE \& Kohrle J 1998 Functional retinoid and thyroid hormone receptors in human thyroid-carcinoma cell lines and tissues. International Journal of Cancer 76 368-376.

Schneiderman J \& Loskutoff DJ 1991 Plasminogen activator inhibitors. Trends in Cardiovascular Medicine 199-102.

Schoenermark MP, Mitchell TI, Rutter JL, Reczek PR \& Brinckerhoff CE 1999 Retinoid-mediated suppression of tumor invasion and matrix metalloproteinase synthesis. Annals of the New York Academy of Sciences 878 466-486.

Schreck R, Schnieders F, Schmutzler C \& Kohrle J 1994 Retinoids stimulate type I iodothyronine $5^{\prime}$-deiodinase activity in human follicular thyroid carcinoma cell lines. Journal of Clinical Endocrinology and Metabolism 79 791-798.

Serini G, Trusolino L, Saggiorato E, Cremona O, De Rossi M, Angeli A, Orlandi F \& Marchisio PC 1996 Changes in integrin and E-cadherin expression in neoplastic versus normal thyroid tissue. Journal of the National Cancer Institute 88 442-449.

Smit JW, Van der Pluijm G, Vloedgraven HJ, Lowik CW \& Goslings BM 1998 Role of integrins in the attachment of metastatic follicular thyroid carcinoma cell lines to bone. Thyroid 8 29-36.

Smit JW, Van der Pluijm G, Romijn HA, Lowik CW, Morreau H \& Goslings BM 1999 Degradation of extracellular matrix by metastatic follicular thyroid carcinoma cell lines: role of the plasmin activation system. Thyroid 9 913-919.

Smit JW, Vielvoye GJ \& Goslings BM 2000 Embolization for vertebral metastases of follicular thyroid carcinoma. Journal of Clinical Endocrinology and Metabolism 85 989-994.

Sudo H, Kodama HA, Amagai Y, Yamamoto S \& Kasai S 1983 In vitro differentiation and calcification in a new clonal osteogenic cell line derived from newborn mouse calvaria. Journal of Cell Biology 96 191-198.

Takeuchi Y, Matsumoto T, Ogata E \& Shishiba Y 1990 Isolation and characterization of proteoglycans synthesized by mouse osteoblastic cells in culture during the mineralization process. Biochemical Journal 266 15-24.

Touhami M, Bourge JF \& Legrand C 1999 Increased adhesion of the promyelocytic leukaemia cell line, NB4, to fibronectin and thrombospondin upon all-trans-retinoic acid treatment. British Journal of Haematology 104 706-714.

Van Bezooijen RL, Farih-Sips HC, Papapoulos SE \& Lowik CW 1998 IL-1 alpha, IL-1 beta, IL-6, and TNF-alpha steady-state mRNA levels analyzed by reverse transcription-competitive PCR in bone marrow of gonadectomized mice. Journal of Bone and Mineral Research 13 185-194.

Van der Pluijm G, Vloedgraven HJ, Ivanov B, Robey FA, Grzesik WJ, Robey PG, Papapoulos SE \& Lowik CW 1996 Bone sialoprotein peptides are potent inhibitors of breast cancer cell adhesion to bone. Cancer Research 56 1948-1955. 
Van Herle AJ, Agatep ML, Padua DN, Totanes TL, Canlapan DV, Van Herle HM \& Juillard GJ 1990 Effects of 13 cis-retinoic acid on growth and differentiation of human follicular carcinoma cells (UCLA R0 $82 \mathrm{~W}-1$ ) in vitro. Journal of Clinical Endocrinology and Metabolism 71 755-763.

Vassalli JD, Sappino AP \& Belin D 1991 The plasminogen activator/plasmin system. Journal of Clinical Investigation $\mathbf{8 8}$ 1067-1072.

Vo HP, Lee MK \& Crowe DL 1998 alpha2 beta1 integrin signaling via the mitogen activated protein kinase pathway modulates retinoic acid-dependent tumor cell invasion and transcriptional downregulation of matrix metalloproteinase 9 activity. International Journal of Oncology 13 1127-1134.
Waghray A \& Webber MM 1995 Retinoic acid modulates extracellular urokinase-type plasminogen activator activity in DU-145 human prostatic carcinoma cells. Clinical Cancer Research 1 747-753.

Webber MM \& Waghray A 1995 Urokinase-mediated extracellular matrix degradation by human prostatic carcinoma cells and its inhibition by retinoic acid. Clinical Cancer Research 1 755-761.

Xing RH \& Rabbani SA 1996 Overexpression of urokinase receptor in breast cancer cells results in increased tumor invasion, growth and metastasis. International Journal of Cancer 67 423-429.

Received 12 April 2000

Accepted 26 June 2000 